\title{
UJI AKTIVITAS ANTIMIKROBA EKSTRAK ETANOL BIJI KEBIUL (CAESALPINIA BONDUS (L.) ROXB) TERHADAP PERTUMBUHAN BAKTERI STAPHYLOCOCCUS AUREUS
}

\section{ANTI MICROBIAL ACTIVITY TEST OF ETHANOL EXTRACT OF KEBIUL'S SEEDS (CAESALPINIA BONDUS (L.) ROXB) ON THE GROWTH OF BACTERIA STAPHYLOCOCCUS AUREUS}

\section{Oleh:}

\author{
Heti Rais Khasanah¹, Diah Eka Nugraheni² \\ 1 Prodi Farmasi, Poltekkes Kemenkes Bengkulu \\ 2 Prodi Kebidanan, Poltekkes Kemenkes Bengkulu \\ e mail : heti_rais@yahoo.com
}

\begin{abstract}
Background: Staphylococcus aureus is a bacterium in the form of a cocci with a diameter of $1 \mu \mathrm{m}$ which is Gram-positive when viewed under a microscope, shaped like grapes. Whale seeds contain saponins, flavonoids and steroids that can inhibit the growth of Staphylococcus aureus bacteria. Purpose: This study aims to determine the antimicrobial activity contained in the white bean extract (Caesalpinia bondus (L.) Roxb) against the growth of Staphylococcus aureus bacteria in various concentrations, using Quasy Laboratory Experiments. The data were tested using the univariate data analysis test, namely to see the average diameter of the inhibition zone from the treatment of each concentration on the white bean. Method: Extraction was carried out using maceration method with ethanol solvent and antibacterial activity test using agar diffusion technique. Conclusion: The ethanol extract of Caesalpinia bondus (L.) Roxb) seeds at various concentrations had an inhibitory power against the growth of staphylococus aureus bacteria. Conclusion: The ethanol extract of Caesalpinia bondus (L.) Roxb) seeds at various concentrations had an inhibitory power against the growth of staphylococus aureus bacteria.
\end{abstract}

Keywords: Caesalpinia bondus (L.) Roxb, Staphylococcus aureus.

\section{ABSTRAK}

Latar Belakang : Staphylococcus aureus adalah bakteri berbentuk kokus berdiameter $1 \mu \mathrm{m}$ yang pada pewarnaan bersifat Gram positif, jika dilihat dibawah mikroskop berbentuk seperti anggur. Biji kebiul mengandung saponin, flavonoid dan steroid yang dapat menghambat pertumbuhan pada bakteri Staphylococcus aureus. Tujuan : Penelitian ini bertujuan untuk untuk mengetahui aktivitas antimikroba yang terdapat di dalam ekstrak biji kebiul (Caesalpinia bondus (L.) Roxb) terhadap pertumbuhan bakteri Staphylococcus aureus dalam berbagai konsentrasi, dengan menggunakan Quasy Eksperimen Laboratorium. Data di uji dengan menggunakan uji analisis data univariat yaitu untuk melihat gambaran rata-rata diameter zona hambat dari perlakuan setiap konsentrasi pada biji kebiul tersebut. Metode: Ekstraksi dilakukan menggunakan metode maserasi dengan pelarut etanol dan uji aktivitas antibakteri menggunakan tehnik difusi agar. Kesimpulan: Extrak ethanol biji kebiul Caesalpinia bondus (L.) Roxb) pada berbagai konsentrasi memiliki daya hambat terhadap pertumbuhan bakteri Staphylococus aureus.

Kata Kunci :Uji aktivitas antibakteri, Caesalpinia bondus (L.) Roxb, Staphylococcus aureus

\section{PENDAHULUAN.}

Pengobatan terhadap penyakit infeksi yaitu dengan cara pemberian antibiotika, antibiotika berfungsi sebagai penghambat atau membunuh mikroba yang menginfeksi. Antibiotika telah banyak ditemukan sekarang ini tetapi beberapa diantaranya menjadi tidak 
efektif digunakan karena banyaknya mikroba yang resisten terhadap antibiotic (Akram.F, Sidra, 2016). Untuk mencegah terjadinya resistensi bakteri terhadap antibiotik perlu dikembangkan penelitian dalam penemuan obat baru yang berasal dari alam. (Brook MS, Philips BE, Wilkinson DJ, 2014).

Tanaman obat berkhasiat ditelaah dan dipelajari secara ilmiah. Hasil penelitian mendukung bahwa tanaman obat memang memiliki kandungan zat-zat atau senyawa yang secara klinis terbukti bermanfaat bagi kesehatan. Kondisi geografis dan keadaan wilayah Provinsi Bengkulu yang masih banyak hutan dimungkinkan banyak ditemukan berbagai jenis tanaman yang digunakan oleh masyarakat sebagai obat tradisional, salah satu jenis tanaman yang digunakan sebagai obat oleh masyarakat adalah biji kebiul (bahasa daerah). (Putra, 2013).

Daerah Bengkulu Selatan banyak ditemukan tumbuhan kebiul. Tumbuhan ini tumbuh secara liar didaerah perkebunan masyarakat, memiliki ciri ciri tumbuhan berbiji tunggal, batangnya merambat dan seluruh permukaannya batang dipenuhi dengan duri yang tajam. Masyarakat suku Serawai di Kabupaten Bengkulu Selatan telah lama menggunakan biji kebiul untuk mengobati berbagai penyakit. Proses penggunaan biji kebiul sebagai obat yaitu dengan disangrai lebih dulu sampai mutung (bahasa Serawai) atau gosong (bahasa Jawa) untuk mengambil daging bijinya kemudian dikonsumsi secara langsung oleh masyarakat sebagai obat tradisional (Kusrahman, 2012). Biji kebiul ini secara tradisional digunakan oleh masyarakat sebagai obat untuk malaria, kencing manis (diabetes melitus), darah tinggi, dan batu ginjal. Menurut pengalaman masyarakat pengobatan menggunakan biji kebiul ini mempunyai efek penyembuhan yang baik (Kusrahman, 2012).

Khasiat suatu tanaman obat sangat erat kaitannya dengan senyawa metabolit sekunder yang tergantung dalam tanaman tersebut. Kemampuan metabolit sekunder dalam tanaman berbeda beda dapat sebagai antimalaria, antidiabetes, antiulcer, antiinflamasi dan antimikroba. Beberapa golongan metabolit sekunder yaitu steroid, terpenoid, turunan fenol, flavonoid dan alkaloid (Raja et al, 2015).

Biji kebiul mengandung senyawa flavonoid, alkaloid, saponin, triterpenoid. (Nazeerullah, Kumar. S Sigh. R, 2012). Berdasarkan uji pendahuluan uji fitokimia di Laboratorium MIPA Biologi Universitas Bengkulu, pada biji kebiul terdapat 3 jenis senyawa aktif yaitu senyawa flavonoid, saponin dan streoid.

Salah satu senyawa biji kebiul yaitu flavonoid memiliki aktivitas mekanisme kerja dalam menghambat pertumbuhan bakteri dan cara inaktivitasi protein (enzim) pada membran sel sehingga mengakibatkan struktur protein menjadi rusak. Ketidakstabilan pada dinding sel dan membran sitoplasma bakteri menyebabkan fungsi permeabilitas selektif, fungsi pengangkutan aktif, pengendalian susunan protein dari sel bakteri menjadi terganggu, yang akan berakibat pada hilangnya makromolekul dan ion dari sel, sehingga sel bakteri menjadi kehilangan bentuk dan terjadi lisis (Rinawati, 2010).

Biji muda kebiul berbentuk bulat, biji berwarna hijau dengan kulit biji yang lunak. Biji tua berwarna abu-abu dengan kulit biji yang sangat keras. Biji terbungkus dalam kelopak yang dipenuhi dengan duri. biji kebiul yang sudah tua dapat di simpan hingga puluhan tahun tampa terjadi kerusakan, biji kebiul memiliki berbagai macam bentuk tergantung tempat tumbuhnya, ada yang berbentuk lonjong, bulat dan ada yang berbentuk tidak beraturan (Putra, 2013).

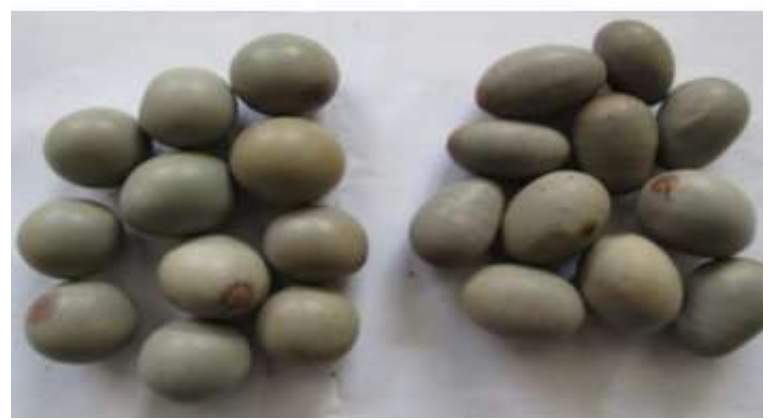

Biji Kebiul.

Sumber: (Putra, 2013)

Metode maserasi digunakan untuk mengekstrak sampel yang realatif tidak tahan 
terhadap pemanasan. Metode ini dilakukan dengan cara merendam sampel dalam suatu pelarut dalam jangka waktu tertentu, biasnya selama 24 jam tanpa menggunakan pemanasan. Kelebihan metode ini diantaranya adalah tidak memerlukan peralatan yang rumit, relatif murah, dapat menghindari penguapan komponen senyawa karena tidak menggunakan panas, sedangkan kelemahanya adalah memerlukan waktu yang lama dan pelarut yang banyak sehingga tidak efisien (Kiswandono, 2011).

Metode pengujian aktivitas antibakteri dapat dilakukan dengan menggunakan cara difusi dan dilusi. Metode disk diffusion atau ayang disebut dengan tes Kirby dan Bauer, distch plate technique, cup plate technique. Metode dilusi cair dan dilusi padat merupakan bagain dari metode dilusi (Aziz, 2010). Terdifusinya senyawa antibakteri ke dalam media padat dimana mikroba uji telah diinokulasikan dalam media padat merupakan prinsip kerja dari metode difusi. Daerah bening yang terbentuk disekitar cakram menunjukan zona hambat pada pertumbuhan bakteri (Balaouri et al, 2016).

Bakteri staphylococcus merupakan bakteri gram positif yang pada saat pewarnaan dengan zat warna kristal violet yodium tetap dipertahankan meskipun diberi larutan pemucat sehingga menghasilkan warna ungu. Pada prosedur pewarnaan gram terdapat haisl yang berbeda pada bakteri gram positif dan gram negatif karaenan struktur luar dinding sel bakteri.Peptodoglikan tebal tanpa lapisan lipoprotein atau lipolisakarida terdapat pada dinding sel terluar bakteri gram positif. Pada bakteri gram negatif pada dinding selnya terdiri dari peptidoglikan tipis yang dibungkus oleh lapisan lipoprotein atau lipoposakarida (ljong, 2015). Staphylococcus aureus dapat menyebabkan penyakit infeksi pada folikel rambut dan kelenjar keringat, bisul, serta infeksi pada luka. Bakteri ini mempunyai kemampuan invansi rendah, terlibat dalam banyak infeksi kulit (Miller et al., 2012).

Terjadinya peningkatan resistensi antibiotik mendorong untuk mencari senyawa yang mampu mengendalikan bakteri, dengan memanfaatakan senyawa bioaktif yang terdapat dalam tanaman. Penelitian ini bertujuan untuk mengetahui adanya aktivitas antibakteri Ektrak etanol Biji Kebiul (Caesalpinia bondus (L.) Roxb) terhadap pertumbuhan bakteri Staphylicoccus aureus.

\section{METODE PENELITIAN}

Penelitian ini menggunakan jenis penelitian Quasy Eksperimen Laboratorium. Penelitian ini menguji aktivitas antimikroba ekstrak etanol biji kebiul (Caesalpinia bondus (L.) Roxb) terhadap pertumbuhan bakteri Staphylococcus aureus.

\section{Alat dan bahan.}

Neraca analitik, kertas perkamen, sendok tanduk, batang pengaduk, alat gelas laboratorium, blender, oven, cawan petri, jarum ose, water bath, cawan penguap, bunsen, autoklaf, spatel, kertas cakram, pinset, gelas beker, erlenmeyer bulat, cling wrap, dan aluminium foil. Bakteri yang digunakan Staphylococcus aureus, Media MHA, aquadest, tetrasiklin, etanol 96\%, ekstrak etanol biji kebiul.

Alat alat yang akan digunakan pada saat penelitian dilakukan sterilisasi dengan sterilisasi udara panas dan kering yaitu seluruh peralatan yang akan digunakan selama penelitian harus dibersihkan dengan cara dicuci kemudian dikeringkan lalu dibungkus dengan kertas alumunium foil atau kertas koran. Kemudian dilakukan sterilisasi di oven selama 2 jam pada suu $180^{\circ} \mathrm{C}$. Sterilisasi basah dilakukan pada erlemeyer dan cawan petri di dalam autoclave dengan suhu $121^{\circ} \mathrm{C}$ dengan tekanan sebesar 15 dyne/cm3 (1 atm) selama 15 menit (Mulyadi, Wuyanti and Ria, 2013).

Populasi dari penelitian ini merupakan tanaman kebiul Caesalpinia bondus (L.) Roxb yang diambil dari daerah Bengkulu Selatan. Sampel dalam penelitian ini diambil dari biji tanaman kebiul, yang kemudian melalui proses pengeringan. Variasi konsentrasi yang diujikan $20 \%, 40 \%, 60 \%, 80 \%$, dan 100\%. Data hasil penelitian dianalisa dengan menggunakan uji univariant. Dengan melihat hasil Zona Hambat 
Pertumbuhan Bakteri dari masing masing konsentrasi ekstrak etanol biji kebiul. Zona hambat ditandai dengan daerah yang bening disekitar kertas uji.

\section{Ektraksi Biji Kebiul}

Pada penelitian ini, biji kebiul (Caesalpinia bondus (L) dikeringkan kemudian dilepaskan dari kulit luar. Biji kebiul yang dikeringkan seberat $2 \mathrm{~kg}$, proses selanjutnya biji yang telah kering disangrai dengan tujuan untuk membantu proses pemisahan biji dari kulit tanduk yang keras. Biji kebiul yang sudah terpisah dari kulit tanduk di haluskan dengan menggunakan blender, hal ini membantu memperluas permukaan yang berinteraksi dengan pelarut sehingga lebih banyak senyawa yang dapat terekstrak. Sampel yang telah dihaluskan diekstraksi. Proses ekstraksi dalam penelitian ini menggunakan metode maserasi.

Maserasi merupakan cara ekstraksi yang paling sederhana. Bahan simplisia yang dihaluskan sesuai dengan syarat farmakope (umumnya terpotong-potong atau berupa serbuk kasar) disatukan dengan bahan pengekstraksi. Selanjutnya rendaman tersebut disimpan terlindung dari cahaya langsung (mencegah reaksi yang dikatalisis cahaya atau perubahan warna) dan dikocok kembali. Waktu lamanya maserasi berbeda-beda antara 4-10 hari. Secara teoritis pada suatu maserasi tidak memungkinkan terjadinya ekstraksi absolute. Semakin besar perbandingan cairan pengekstraksi terhadap simplisia, akan semakin banyak hasil yang diperoleh (Kusrahman, 2012).

Tahapan maserasi yang dilakukan adalah dengan menghaluskan biji kebiul, setelah biji kebiul halus dimasukkan ke dalam botol coklat besar untuk dilakukan proses maserasi selama 5 hari. Bji kebiul diredam dengan menggunakan pelarut ethanol $96 \%$ sampai biji kebiul terendam seutuhnya. Simpan rendaman biji kebiul tersebut ditempat yang terlindung dari cahaya matahari langsung dan dikocok berulang kirakira sebanyak 3 kali sehari dalam 5 hari. Setelah 5 hari, larutan biji kebiul disaring dan disimpan diwadah lain, kemudian ampasnya dimaseri lagi selama 2 hari dengan perlakuan yang sama. Hasil maserasi dari biji kebiul disaring dan dicampurkan menjadi satu. Setelah ekstrak etanol biji kebiul disaring dipekatkan dengan menggunakan rotary evaporatory dengan suhu $50^{\circ} \mathrm{C}$ sampai diperoleh ekstrak kental biji kebiul yang selanjutnya akan dilakukan pengeceran (Padmasari, Astuti and Warditiani, 2012).

Pelarut ekstraksi menggunakan etanol. Etanol merupakan pelarut yang tidak berancun, dan bersifat universal yang cocok untuk disaring kembali untuk memisahkan garam dari ekstrak dengan tujuan agar dalam pengujian antibakteri garam tidak mengganggu penghambatan bakteri. Pelarut etanol mempunyai titik didih yang rendah dan cenderung aman.Pelarut etanol memiliki titik keporan yang tinggi sehingga akan mudah untuk melarutkan senyawa yng mengnaudng resin, lemak, minyak, asam lemak, karbohodrat dan senyawa organik lainnya (Munawarah \& handayani 2010).

Hasil ekstraksi selanjutnya diuapkan dengan menggunakan rotary evaporator untuk memisahkan pelarut dengan ekstrak. Ekstrak kental yang didapat berwarna coklat seperti pasta dengan bau seperti kopi.

\section{HASIL PENELITIAN}

\section{Uji Aktivitas Antibakteri}

Uji aktivitas antibakteri ekstrak etanol biji kebiul, dilakukan dengan metode difusi agar. Menurut Pratiwi, 2010 metode disc diffusion untuk menentukan aktivitas agen antimikroba dengan menggunakan paper disc. Pengertian dari disc diffusion merupakan piringan yang berisi agen antimikroba yang diletakkan pada media agar yang telah ditanami mikroorganisme yang akan berdisfusi pada media agar tersebut. Area jernih disekitar paper disc mengindikasikan adanya hambatan pertumbuhan mikroorganisme oleh agen antimikroba pada permukaan media agar.

Prinsip dari metode difusi agar yang digunakan dalam penelitian ini, aktivitas antimikroba dilihat dengan cara melakukan pengukuran daya hambat aktivitas bakteri dengan melihat zona bening yang terbentuk disekitar paper disc. Zona bening merupakan 
area dimana tidak terjadi pertumbuhan bakteri, jika daerah zona hambat ada satu koloni saja koloni pertumbuhan bakteri maka dianggap tidak ada zona hambat. Paper disc yang ditetesi dengan ekstrak etanol biji kebiul dengan konsentrasi 20\%, 40\%, 60\%, 80\% dan 100\% dimasukkan dalam media MHA yang sudah diinokulasi dengan bakteri uji.

Bakteri yang digunakan dalam pengujian adalah bakteri Staphylococus aureus. Merupakan bakteri gram positif, yang memiliki ciri ciri berbentuk bulat bulat berdimaeter 0.7-1,2 $\mu \mathrm{m}$, tersusun dalam kelompok kelompok yang tidak teratur seperti buah anggur, fakultatif anaerob, tidak membentuk spora, dan tidak bergerak. Berdasarkan bakteri yang tidak membentuk spora, maka S.aureus termasuk jenis bakteri yang paling kuat daya tahannya. Penyimpanan pada agar miring dalam lemari es ataupun suhu ruangan dapat tetap hidup sampai berbulan bulan. Dapat bertahan hidup selama 6 -14 minggu pada benang, kertas, kain dan dalam nanah pada kondisi kering (Syahrurahman et al, 2010).

Uji aktivitas antibakteri ekstrak etanol biji kebiul dilakukan untuk memastikkan bahwa kandungan senyawa aktif dalam ekstrak memiliki kemampuan menghambat pertumbuhan bakteri Staphylococus aureus. Hasil diperoleh melalui pengamatan selama $1 \mathrm{x}$ 24 jam masa inkubasi dengan 3 kali pengulangan. Hasil uji aktivitas antibakteri dan hasil pengukuran diameter zona hambat ekstrak etanol biji kebiul (Caesalpinia bondus ( $L$ ) terhadap bakteri Staphylococus aureus dapat dilihat pada tabel 1.

Tabel 1. Hasil Uji Aktivitas Antibakteri Ekstrak Etanol Biji Kebiul (Caesalpinia bondus (L) Terhadap pertumbuhan bakteri staphylococus aureus.

\begin{tabular}{|c|c|c|c|}
\hline \multicolumn{4}{|c|}{ Diameter Zona Hambat (mm) } \\
\hline \multirow[t]{2}{*}{ Konsentrasi } & $\begin{array}{l}\text { Pengulangan } \\
3 \text { kali }\end{array}$ & $\begin{array}{l}\text { Kekuata } \\
n\end{array}$ & $\begin{array}{l}\text { Efektivitas } \\
(\%)\end{array}$ \\
\hline & $\begin{array}{ll}\text { Rata } & \text { Rata } \\
(\mathrm{mm}) & \end{array}$ & & \\
\hline $20 \%$ & 6.75 & Sedang & $34.61 \%$ \\
\hline $40 \%$ & 7.75 & Sedang & $39.74 \%$ \\
\hline
\end{tabular}

\begin{tabular}{llll}
\hline $60 \%$ & 8.25 & Sedang & $42.30 \%$ \\
\hline $80 \%$ & 8.75 & Sedang & $44.87 \%$ \\
\hline $100 \%$ & 9.75 & Sedang & $50 \%$ \\
\hline Kontrol $(+)$ & 19.50 & Kuat & $100 \%$ \\
\hline Kontrol $(-)$ & 0 & 0 & $0 \%$ \\
\hline
\end{tabular}

Davis dan Stout, menyatakan bahwa apabila zona daya hambat yang terbentuk pada uji difusi agar berukuran kurang dari $5 \mathrm{~mm}$, maka aktivitas penghambatannya dikategorikan lemah. Apabila zona daya hambat berukuran 5$10 \mathrm{~mm}$ dikategorikan sedang, $10-19 \mathrm{~mm}$ dikategorikan kuat dan $20 \mathrm{~mm}$ atau lebih dikategorikan sangat kuat. Pegujian aktivitas antibakteri dilakukan dengan tiga kali pengulangan untuk masing masing konsentrasi. Diperoleh hasil bahwa ekstrak etanol biji kebiul (Caesalpinia bondus ( $L$ ) mampu menghambat bakteri stahphylococus aureus dalam kategori sedang, pada konsentrasi yang paling tinggi yaitu $100 \%$ luas daya hambat mendekati kuat. Dilihat dari tabel hasil semakin tinggi konsentrasi ekstrak etanol biji kebiul yang diberikan semakin meningkat luas zona hambat terhadap bakteri Staphylococus aureus. Bakteri Gram positif cenderung lebih sensitif terhadap antibakteri karena struktur dinding sel bakteri gram positif lebih sederhana dibandingkan struktur dinding sel bakteri Gram negatif sehingga memudahkan senyawa antibakteri untuk masuk ke dalam sel bakteri Gram positif (Yunita, 2012)

Kontrol positif yang digunakan tetrasiklin yang memiliki aktivitas antibakteri paling kuat yaitu $19.50 \mathrm{~mm}$. Tetrasiklin termasuk antibiotik yang terutama bersifat bakteriostatik dan bekerja dengan jalan menghambat sintesisi protein kuman. Tetrasiklin diserap oleh bakteri yang peka dan menghambat pembentukan protein dengan menghambat pengikatan aminoasil tRNA pada unit 30S pada ribosom bakteri.

Efek antibakteri ini berasal dari senyawasenyawa yang terdapat pada biji kebiul yaitu flavonoid, steroid dan saponin. Persenyawaan Flavonoid adalah suatu kelompok senyawa fenol dengan terbesar dan memiliki mekanisme kerja dalam menghambat pertumbuhan bakteri 
dan cara inaktivitasi protein (enzim) pada membran sel sehingga mengakibatkan struktur protein menjadi rusak. Ketidakstabilan pada dinding sel dan membran sitoplasma bakteri menyebabkan fungsi permeabilitas selektif, fungsi pengangkutan aktif, pengendalian susunan protein dari sel bakteri menjadi terganggu, yang akan berakibat pada hilangnya makromolukel dan ion dari sel, sehingga sel bakteri menjadi kehilangan bentuk dan terjadi lisis (Rinawati, 2010). Flavonoid yaitu dengan menyebabkan kerusakan permeabilitas dinding sel bakteri dan menghambat motilitas bakteri (Darsana, 2012).

Menurut Taroreh 2016, steroid merupakan senyawa triterpenoid yang diduga mekanisme kerja penghambatan bakteri dengan cara merusak membran sel sehingga terjadi kebocoran sel. Steroid sebagai antibakteri berhubungan dengan membran lipid dan sensitivitas terhadap komponen steroid yang menyebabkan kebocoran pada liposom menyebabkan integritas membran menurun serta morfologi membran sel berubah yang menyebabkan sel rapuh dan lisis (Ji Ys, 2012).

Selain itu saponin yang terkandung dalam biji kebiul bersifat surfaktan yang berbentuk polar sehingga akan memecah lapisan lemak pada membran sel yang ada pada akhirnya menyebabkan gangguan permeabilitas membran sel, hal tersebut mengakibatkan proses difusi bahan atau zat-zat yang diperlukan oleh jamur dapat terganggu, akhirnya membengkak dan pecah (Sugianitri, 2011). Saponin menurunkan tegangan permukaan karena memiliki sifat seperti sabun. Diabsorbsi pada permukaan sel akan mengakibatkan kerusakan membran sel dengan naiknya permeabilitas membran atau kebocoran sel sehingga menyebabkan kematian sel karena hilangnya bahan bahan esensial sel (Natala et al, 2014). Saponin memiliki molekul yang dapat menarik air atau hidrofilik dan molekul yang dapat melarutkan lemak atau lipofilik sehingga dapat menurunkan tegangan permukaan sel yang akhirnya menyebabkan hancurnya bakteri (Ji Ys, 2012).

Kontrol negatif yang digunakan dalam penelitian ini yaitu aquadest, dari pengujian kontrol negatif menunjukan tidak adanya zona hambat terhadap bakteri gram negatif Staphylococus aureus. Hal ini mengindikasikan bahwa kontrol yang digunakan tidak berpengaruh pada uji aktivitas antibakteri, sehingga daya hambat yang terbentuk tidak dipengaruhi oleh pelarut melainkan karena aktivitas senyawa yang ada pada ekstrak etanol biji kebiul. Kontrol positif menunjukkan perbedaan yang nyata, karena menghasilkan aktivitas antibakteri yang paling besar terhadap bakteri uji dibanding kontrol negatif dan ekstrak etanol biji kebiul. Kontrol positif yang digunakan dalam pengujian ini adalah tetrasiklin. Tetrasklin merupakan antibiotika yang memperlihatkan spektrum luas pada bakteri garm positif dan negatif, aerob dan anaerob, selain itu juga aktif terhadap spiroket, mikroplasma, rickettsia, klamidia, legionella, dan protozoa.

\section{KESIMPULAN DAN SARAN}

\section{KESIMPULAN}

Ekstrak etanol biji kebiul (Caesalpinia bondus (L) efektif dalam menghambat pertumbuhan bakteri Stahphylococus aureus dengan kategori sedang berdasarkan kriteria Davis dan Stoud. Rata rata diameter zona hambat ekstrak etanol biji kebiul pada Stahphylococus aureus dengan konsentrasi $20 \%, 40 \%, 60 \%, 80 \%$ dan $100 \%$ yaitu $6,75 \mathrm{~mm} ; 7,75 \mathrm{~mm} ; 8,25 \mathrm{~mm} ; 8,75 \mathrm{~mm}$; $9,75 \mathrm{~mm}$. Dari hasil pengukuran diabeter zona hambat yang diperoleh, ektrak etanol biji kebiul berbeda dengan kontrol positif Tetrasiklin. Hal ini menunjukan bahwa Ekstrak etanol biji kebiul memiliki aktivitas antibakteri tetapi tidak lebih besar dari Tetrasiklin.

\section{SARAN}

Berdasarkan hasil serta pembahasannya maka perlu dilakukan penelitian lebih lanjut dengan menggunakan pelarut lain dan menggunakan bakteri uji yang lain. 


\section{DAFTAR PUSTAKA}

Akram, F. E. et al. (2016) 'A combination of silver nanoparticles and visible blue light enhances the antibacterial efficacy of ineffective antibiotics against methicillinresistant Staphylococcus aureus (MRSA)', Annals of Clinical Microbiology and Antimicrobials. BioMed Central, 15(1), p. 48. doi: 10.1186/s12941-0160164-y.

Balouiri, M., Sadiki, M., \& Ibnsouda, S.K. (2016) Methods for in vitro Evaluating Antimicrobial activity: A review. Journal of Pharmaceutical Analysis, 6(2): 71-79

Darsana, I.G.O., Besung, I.N.K., Mahatmi, H. (2012). Potensi binahong (Anredera cordifolia (Tenore) Steenis) dalam menghambat pertumbuhan bakteri Escheria coli secara in vitro. Indonesia Medicus Vaterinus, 1(3), 337-351

ljong, FG, 2015. Mikrobiologi Perikanan dan Kelautan. Jakarta (ID) : Rineka Cipta

Ji YS., Lestari, N.D., Rinanda, T. (2012). Uji Aktivitas antibakteri ekstrak etanol 30\% dan $96 \%$ kelopak bunga rosella ( Hibiscus sabdariffa) terhadap bakteri Streptococcus pyogenes secara in vitro. Jurnal Kedokteran Syiah Kuala, 12(1), 3136

Kiswandono, A.A, 2011. Skrining Senyawa Kimia dan Pengaruh Metode Maserasi Dan Refluks Pada Biji Kelor (Moringa oleifera, Lamk) Terhadap Redeman Ekstrak yang dihasilkan. Jurnal Sains Natural Universitas Nusa Bangsa.Vol1, No 2.

Kusrahman, A. (2012) Isolasi, Karakterisasi Senyawa Aktif dan Uji Farmaka Ekstrak Biji Kebiul pada Mencit (Mus musculus) Serta Penerapannya dalam Pembelajran Kimia di SMAN 1 Bengkulu Selatan. Universitas Bengkulu.

Mulyadi, M., Wuyanti and Ria, P. (2013) 'Konsentrasi Hambat Minimum (KHM)
Kadar Sampel Alang-Alang (Imperata cylindrica) Dalam Etanol Melalui Metode Difusi Cakram', Universitas Diponegoro, $1(1)$, pp. 35-42.

Munawarah, S. \& Handayani, P.A., 2010. Ekstraksi minyak daun jeruk purut (cytrus hydtrik D.C) N-Heksan, Jurnal Kompetensi Teknik

Nazeerullah, K. et al. (2012) 'A pharmacognostic and pharmacological overview on Caesalpinia bonducella', Research Journal of Pharmaceutical, Biological and Chemical Sciences, 3(1), pp. 440-496.

Netala, V.R.,Ghosh, S.B.,Bobbu.P., Anitha, D., dan Terte, V.,2014, Triterpenoid saponin: a review on biosynthesis, applications and mechanism of their action. International Journal of Pharmacy and Pharmaceutical Sciences, 7 (1).

Padmasari, Astuti and Warditiani (2012) 'Skrining fitokimia ekstrak etanol $70 \%$ rimpang bangle (Zingiber purpureum Roxb.)', Universitas Udayana, 366, pp. 17.

Putra, A. R. I. O. (2013) Elektroforesis dan Uji Hemaglutinasi Lektin Biji Kebiul pada Darah Golongan ABO dan Sebagai Model Pembelajaran Audio-Visual untuk Meningkatkan Hasil Belajar Kimia. Universitas Bengkulu.

Raja R, Sreenivasulu M. (2015). Medical plant ecodary metabolits used in pharmaceutical impotance on overview. Word Journal of Pharmacy and Pharmaceutical Science

Rinawati, N. D. (2010) 'Daya Antibakteri Tumbuhan Majapahit ( Crescentia cujete L .) Terhadap Bakteri Vibrio alginolyticus', Surabaya, pp. 1-13.

Sugianitri, N. (2011) 'Ekstrak biji buah pinang (Areca catechu L.) dapat menghambat pertumbuhan koloni Candida albicans secara in vitro pada resin akrilik heat cured', Denpasar, p. 68. 
Taroreh, T. N. C., Rumampuk, J. F. And Siagian, K. V. (2016) 'Uji Daya Hambat Ekstrak Daun Melinjo ( Gnetum Gnemon L . ) Terhadap Pertumbuhan Bakteri Streptococcus Mutans', Pharmacon, 5(3), Pp. 160-166.

Yunita, D.W. (2012. Aktivitas antibakteri ekstrak etanol kayu secang (Caesalpinia sappan L.) terhadap Staphylococcus aureus atcc 25923, Shigella sonnei atcc 9290, dan Escherichia coli atcc 25922. Skripsi. Surakarta: Universitas Muhammadiyah Surakarta 